\title{
WHITMAN'S END OF HISTORY: “AS I SAT ALONE BY BLUE ONTARIO'S SHORE," DEMOCRATIC VISTAS, AND THE POSTBELLUM POLITICS OF NOSTALGIA
}

\author{
Thomas F. Haddox
}

As RECENTLY AS FIFTEEN YEARS AGo, Betsy Erkkila could justifiably complain in Whitman the Political Poet that "the Whitman we have learned to read in the academy and among the critics comes to us curiously purified of his political designs" - an effect that she attributed both to the long influence of New Criticism and to the tradition of "spiritual" readings inaugurated by such early advocates of Whitman as Richard Maurice Bucke. ${ }^{1}$ There seems little danger, however, that Whitman remains "purified" of his political designs today. In the work of his most fervent admirers, we have seen Whitman the spiritual visionary, whose achievement was fundamentally religious and whose most overtly political work was something of an embarrassment, give way to Whitman the exemplary queer, a prophet whose celebration of bodily pleasures and fluid sexualities is inseparable from a radical critique of Enlightenment individualism. ${ }^{2}$ Meanwhile, even those readers who take a more critical stance toward him, stressing, for instance, the contradiction between the egalitarianism of his best poems and the conventional racism of his journalism and correspondence, have often tried to resolve this contradiction in the most generous way, even sometimes going so far as to cast it as a highly eroticized opportunity for transgression that may itself be a political virtue. ${ }^{3}$

Both the long silence surrounding Whitman's politics and the current widespread affirmation of them, however, can be attributed to the characteristic way his work collapses his subjectivity and the national will into a single whole. ${ }^{4}$ This collapse allows him to evade the problem of political representation - the question, crucial for subjects of a modern nation-state, of how to create mediating structures between citizens and their government and negotiate competing political claims. By identifying the national will with the poet's, Whitman invites those inclined toward religious interpretation to read him as a mystic, indifferent to the particulars of everyday political conflict and ready to leap beyond them into assertions of One Identity. At the same time, the heterogene- 
ity contained within this mystic vision appears thoroughly political to those who hold racial and sexual diversity as a supreme good and regard the sovereign individual of the American political tradition as both product and producer of an oppressive ideology. In either case, what is excluded is precisely what Whitman himself excludes: intractable struggle and the possibility of irreconcilable positions.

This refusal to recognize intractable conflicts manifests itself in Whitman's aesthetic of lists and catalogues, in which a potentially endless proliferation of objects nevertheless coheres into a single visionary whole. In turn, this aesthetic practice implies an epistemology, for Whitman himself, as the perceiving subject, both subsumes these objects into his single vision and declares himself coterminous with it: as he put it in "So Long!," "Camerado, this is no book, / Who touches this, touches a man." Terry Eagleton, in The Ideology of the Aesthetic, considers the epistemological implications of aesthetic theory in terms that seem applicable to much of Whitman's œuvre:

That the individual subject should come to occupy centre stage [in the eighteenth century], reinterpreting the world with reference to itself, follows logically enough from bourgeois economic and political practice. But the more the world is thus subjectivized, the more this all-privileged subject begins to undermine the very objective conditions of its own pre-eminence. The wider the subject extends its imperial sway over reality, the more it relativizes that terrain to its own needs and desires, dissolving the world's substance into the stuff of its own senses. Yet the more it thereby erodes any objective criteria by which to measure the significance or even reality of its own experience. The subject needs to know that it is supremely valuable; but it cannot know this if its own solipsism has cancelled out any scale by which such value might be assessed. What is this subject privileged over, if the world has been steadily dwindled to no more than an obedient mirror image of itself? ${ }^{6}$

Whitman's own extension of his "imperial sway over reality" is, of course, something of a cliché. "Do I contradict myself?" he famously asks in "Song of Myself." "Very well then I contradict myself, / (I am large, I contain multitudes)" (82). If these "multitudes," as Eagleton suggests, constitute a "dissolving of the world's substance" into Whitman's own experience, then they should indeed confirm Whitman the poet as "supremely valuable." Yet in Whitman's poems this process just as frequently reverses itself, so that the poet's importance lies not in his being privileged "over" these objects, but in merging his subjectivity with them. The long catalogues of objects and persons that structure many of his poems, the attempts to give voice to figures strikingly different from himself (as, for example, in "Ethiopia Saluting the Colors," which imagines the speech of a recently freed slave), have a double effect. On the one hand, there is the irreducible diversity of these objects and figures and the sublime egotism of the poet who can force such materials into an expression of will. On the other, the distinctions be- 
tween these objects and figures tend to disappear (since they figure as interchangeable items in a list), as does any distinct expression of poet's subjectivity itself - a phenomenon that D. H. Lawrence observed as early as 1923 when he argued that Whitman's poems culminate in a celebration of death. ${ }^{7}$ What Kerry A. Larson has called Whitman's "drama of consensus" - an identification with the reader that Whitman invokes by addressing a "you" in many of the poems-becomes prescriptive: the constant assertions of communion between poet and reader preclude dialogue and amount to an immediate guarantee of assent that must be maintained if the poet is to avoid a thoroughgoing solipsism. ${ }^{8}$

Political conflicts, however, do not easily resolve into One Identity, and when Whitman breezily accepts contradiction, he does not mean that he identifies with every possible political position. Despite his frequent shifts in opinion over the course of his career, he always expresses his convictions in oppositional terms, stating at any given moment what he believes and what he rejects, sometimes rising to vitriolic denunciation of the national scene in such poems as "Respondez!" and such political writings as "The Eighteenth Presidency!" Aware that his need to take political stands conflicts with his desire to encompass everything, Whitman most often squares the circle by maintaining that apparent conflicts disappear within the greater unity that he, as the poet of America, both perceives and continually creates. This strategy has the self-serving effect of implying that those who disagree with him are either really in accord with him at some deeper, essential level, or else utterly foreign to him and to America. Claiming for himself Shelley's title of unacknowledged legislator, Whitman typically reduces the complexity of American political debate to an abiding faith that his own poetic will can accomplish unanimity in diversity. It may well be, as Larson argues, that Whitman harbors significant doubts as to the political efficacy of literature, that "he is bent on persuading himself of this faith no less than ourselves" (xxi). And yet even if we grant the sincerity of Whitman's radicalism and empathize with his doubts, the desire to transform conflict into mystic union that animates much of his work renders effective political engagement all but impossible.

In this essay I will examine three texts that foreground Whitman's desire to impose unity on, and thus neutralize, political conflicts: the 1856 "Poem of Many In One"; its 1867 revision, "As I sat Alone by Blue Ontario's Shore" (which would become "By Blue Ontario's Shore" in the 1881 edition of Leaves of Grass); and the 1871 prose work Democratic Vistas. All three texts assert national unity with strident optimism, but the two postwar texts, appearing within the divisive historical context of Reconstruction, cannot help but acknowledge the fragility of the Union and consider how it was nearly destroyed. The most fiercely contested political issues of the day - the enfranchisement of African-Ameri- 
cans and the reconstitution of the Union-were fundamental, engaging both the need to reimagine the United States as a community and the practical problem of the relationship between democracy and representation. ${ }^{10}$ Yet in both "Ontario's Shore" and Democratic Vistas, Whitman does little more than allude to these issues before he moves past them, gesturing toward a future in which the conflicts have been resolved even as he continues to invoke the same model of national identity that he had championed in "Poem of Many In One." One searches in vain for any intimation that the post-Civil War Union, however alarming its situation, is anything but a single family, rapidly forgetting its recent fratricidal struggle. By declaring himself national bard, Whitman in fact reveals his own nostalgic inefficacy and imposes on his verse a political vision that could only be realized (if at all) through debate and conflict. Indeed, Whitman's growing interest in the philosophy of Hegel, particularly evident in Democratic Vistas, suggests that he believes history in any meaningful sense to be at an end, that the democratic millennium is at hand, and that it will, despite all appearances to the contrary, progress unstoppably to its complete realization-a position all too amenable to conservatism and complacency. Whitman's interest in Hegel, however, does not so much mark a departure from an earlier, more egalitarian politics as the discovery of a more useful philosophical touchstone for the politics he had already professed. In other words, contrary to what others have argued, I discern no conservative "turn" in Whitman's work following the Civil War; I maintain instead that the conservatism always implicit in his political vision only becomes explicit once the Civil War and his turn to Hegel reveal the limitations of that vision.

The poem known today as "By Blue Ontario's Shore" is the most revised of Whitman's longer poems. It first appeared under the title "Poem of Many In One" in the 1856 edition of Leaves of Grass, then underwent a number of minor changes before being placed as the first poem of the "Chants Democratic" cluster in the 1860 edition. Between 1860 and 1867 Whitman revised the poem considerably, expanding it from fifteen sections to twenty, situating its argument within a narrative frame, and interpolating into its structure a number of passages in parentheses about "Democracy." Retitled "As I sat Alone by Blue Ontario's Shore," the poem introduces the "Songs Before Parting" annex in the 1867 Leaves of Grass, where it becomes a sustained meditation on the poet's role in the transformed conditions of postbellum America. ${ }^{11}$ In many respects, "As I sat Alone by Blue Ontario's Shore" propounds the same identification of the poet with the United States that characterizes the earlier poem. Yet in the new and unforeseen climate of Reconstruc- 
tion, such identification becomes more problematic, and a comparison of the 1856 and 1867 versions of the poem reveals that Whitman's revisions testify to the increased strain on his enterprise.

"Poem of Many In One" begins with these lines:

\section{A nation announcing itself,}

I myself make the only growth by which I can be appreciated,

I reject none, accept all, reproduce all in my own forms. (190-191)

From the very beginning, poet and nation are made interchangeable through the grammatical apposition of "A nation announcing itself" with "I myself." As a result, the second and third lines take on a double meaning: the poet is a product of the nation-indeed, the only product that allows the nation to be "appreciated" - but at the same time, the poet makes the nation, which is likewise the "only growth" that validates the poet's worth. The poet/nation is a great assimilator and transformer, "reject[ing] nothing" but incorporating all within its "forms"-a strategy that accurately describes Whitman's obsessive cataloguing. The next lines, which shift to the first person plural, continue this conflation of poet and nation, in effect raising the possibility that "we" are simultaneously Whitman, Whitman's creation, and potential poets ourselves: "A breed whose testimony is behaviour / What we are, we are-nativity is answer enough to objections" (191). Moreover, if there is a fundamental equivalence of poet, nation, and "us," there is also an equivalence of identity and action: our "testimony" and "behaviour" are inseparable from our "nativity" and our tautological assertion of what "we are." Here is a "multitude" indeed, one that merges the subjectivity of all Americans into a single, undifferentiated will that the poet both creates and reflects. Within such a whole, political representation becomes an absurdity: there is no gap among the people, their will, and their nation that would require any sort of mediation.

This equation of poet, people, and nation illustrates, in an almost brutally belabored fashion, the notion of authority that Mark Maslan identifies in other poems as central to Whitman's project - an authority that is, paradoxically enough, constituted only by his possession, by his renunciation of an individual self in order to channel an impersonal poetic power. Such a definition of poetic authority is, of course, familiar in other guises as the Romantic theory of inspiration or the Platonic account of poetry as divine madness. ${ }^{12}$ In "Poem of Many In One," the authority achieved by Whitman includes a challenge to his countrymen to realize-through their own poetry-the same all-embracing identification with poet and the nation in which they already participate but of which they may not yet be aware. The introduction of a "you" in section 3-"Have you thought there could be but a single supreme?" (191)may seem at first to refer to a subjectivity beyond the poet's reach. Yet 
it quickly becomes clear that the "you" marks an internal dialogue as much as an exhortation to others: the power that has impelled the poet to speak also poses questions and challenges to him that apply equally to "us." The concluding line of section 3, for instance- "Produce great persons, the rest follows" (192)—refers simultaneously to Whitman's need to create himself as a great person, to the nation that has already demonstrated its greatness by producing Whitman, and to the people whose salvation is continually guaranteed by the production of great Persons. The equivalence of the three terms remains unbroken, however tortured its logic becomes.

What, then, is the aesthetic program of this trinity of poet, nation, and people? "Poem of Many In One" is one of Whitman's many manifestos, and indeed, roughly a fourth of its 280 lines are taken almost verbatim from the more widely known Preface to the 1855 edition of Leaves of Grass. ${ }^{13}$ These borrowed passages are largely concerned with defining an American literary tradition and its relationship to other literatures-as in, for instance, this excerpt:

America, curious toward foreign characters, stands sternly by its own,

Stands removed, spacious, composite, sound,

Sees itself promulger of men and women, initiates the true use of precedents,

Does not repel them or the past, or what they have produced under their forms, or amid other politics, or amid the idea of castes, or the old religions,

Takes the lesson with calmness, perceives the corpse slowly borne from the eating and sleeping rooms of the house,

Perceives that it waits a little while in the door, that it was fittest for its days, that its life has descended to the stalwart and well-shaped heir who approaches, and that he shall be fittest for his days. (193)

This passage implies a dialectical conception of American literature: Americans can learn from the achievements of the past, but only by opposing them and then "initiat[ing] the true use of precedents" by incorporating what is best in these works into new and transformed forms. To "initiate the true use of precedents," however, is not only to sublate the achievements of the past, but also to provoke anxiety in those poets who follow. Indeed, this passage anticipates Whitman's challenge to his successors, and when this challenge finally appears in section 12, its difficulty is evident: "He [who aspires to be an American poet] shall surely be questioned beforehand by me with many and stern questions. / Who are you that would talk to America?" (201). Becoming a poet means achieving the same consciousness of union with America that Whitman enjoys and that is potentially open to all: "What is this you bring [to] my America? / Is it uniform with my country?" (202). Even as Whitman calls for others to surpass him-as he must be surpassed, given his dialectical vision of literary history-he defines their achievement as a coming to consciousness that will replicate his own 
and ensure his continued greatness. Indeed, the only point in the poem at which a separation between Whitman and America occurs is also the poem's most grandiose moment, for it explicitly subordinates nation to poet: "It is not the earth, it is not America who is so great, / It is I who am great or to be great" (206). Such a stacking of the cards against potential rivals - even while claiming to share the same identity with them-is simultaneously self-abnegating and an audacious declaration of omnipotence that Harold Bloom would admire. ${ }^{14}$

What this celebration of the untrammeled poetic self lacks is any consciousness of history as the matrix within which literary creation takes place. Section 5 (section 6 in the poem's final version), for example, which contains the poem's expected catalogue of objects, begins as a geographical paean, a litany of rivers, coasts, forests, and varied landscapes (194-195). When this catalogue modulates into a social portrait, it portrays America as a historical constant, whose political motions are as regular as clockwork: "The Union, always swarming with blatherers, and always calm and impregnable ... Congress convening every December, the members duly coming up from the uttermost parts" (195, my emphasis). The catalogue then ends with an inventory of the common people's virtues and occupations, which are likewise treated as expressions of the nation's essential, unchanging character (195-196). To be sure, the poem does demand that future poets know their history and study their political institutions: "Have you considered the organic compact of the first day of the first year of the independence of The States? / Have you possessed yourself of the Federal Constitution?" (201). Even here, however, American history figures not only as a mythic past, but also as an "organic compact" not subject to revision rather than as an ongoing process of conflicts, alliances, and contingencies. History is presented not as a set of forces influencing the poet's work, but as yet another aspect of the same tripartite unity that encompasses him.

The 1867 version of "As I sat Alone by Blue Ontario's Shore," however, can no longer present a poet at one with his history, for the recent Civil War not only disrupted the nation's political rhythms, it nearly destroyed the Union altogether. The first section of the 1867 poem, a complete addition, alludes to the war through a frame narrative:

\section{As I sat alone, by blue Ontario's shore,}

As I mused of these mighty days, and of peace return'd, and the dead that return no more,

A Phantom, gigantic, superb, with stern visage, accost'd me,

Chant me a poem, it said, of the range of the high Soul of Poets,

And chant of the welcome bards that breathe but my native air-invoke those bards;

And chant me, before you go, the Song of the throes of Democracy. 
(Democracy - the destined conqueror-yet treacherous lip-smiles everywhere, And Death and infidelity at every step.) (190)

This version of the poem begins not with an immediate equation of poet and nation, but with a demand by a "Phantom," whose "stern visage," implicitly masculine gender, and ghostly nature recall the Civil War in all its "gigantic, superb" awfulness. Although this passage echoes a classical invocation to a muse, it is significant that it is the Phantom, rather than the poet, who initiates the exchange between them. The poet may renounce his self-possession to chant the song of the "throes" of democracy willingly enough, but he is nevertheless compelled to do so because he has tried to suppress the reality of the war and its effects. As soon as he relegates the war to the past by speaking of the "dead that return no more," the dead contradict him, returning in the form of the Phantom, demanding a claim on the present. The bards of the past and present are needed precisely because the work of the dead - the preservation of Democracy - is unfinished: the Union may have been saved, but as the first parenthetical interpolation shows, "Death and infidelity" are still "at every step." The poet attempts to rise to the call not because he and America are one, but because immediate dangers demand a strong affirmation of democratic values. He thus reveals that he is subject to history, rather than at one with it.

In attempting to sing the song of Democracy, however, he moves immediately into the lines which began the 1856 version of the poem and so reverts to his familiar strategy of identification with nation and people. The certainty of his claims, however, is already called into question by the "dangers" mentioned in the first section. Significantly, the poem rarely spells out just what these "dangers" are, and even its occasional attempts to be more specific prove either vague or improbable. In section 6 , for instance, the poem concludes its catalogue of the people's virtues with an abrupt shift: "Slavery-the murderous, treacherous conspiracy to raise it upon the ruins of all the rest, / On and on to the grapple with it-Assassin! then your life or ours be the stake-and respite no more" (196). It is as if the speaker, in the midst of enumerating the people's virtues, suddenly lashes out because he has been reminded of something that has the potential to destroy these virtues. It may be that here "slavery" should be interpreted more broadly, as any form of potential subordination, since otherwise the reference to it as an ongoing problem would be anachronistic in 1867. And yet given the poem's avowed task of revivifying the national compact, the reference seems jarring, for it is unclear how exactly the "slavery" of, for instance, industrial capitalism or bureaucracy would necessarily preclude national unity. ${ }^{15}$ At another point, in section 3 , the poem warns against the influence of foreign art on American artists: 
I say that works made here in the spirit of other lands, are so much poison to

These States.

How dare these insects assume to write poems for America?

For our armies, and the offspring following the armies. (192)

Not only does this warning seem to contradict the poem's statements elsewhere that America can learn from and build upon the poetic traditions of Europe and Asia (which may explain why Whitman deleted these lines from the final, 1881 version of the poem), it also suggests an attempt to avoid confronting more pressing problems. After all, in 1867 it was precisely the internal threats to the Union - tension between North and South, whites and freed blacks, labor and capital — that commanded attention. Whitman appears to connect the threat of foreign art with the specter of decadence and effeminacy: "Fear grace-Fear delicatesse . . . Beware what precedes the decay of the ruggedness of states and men" (193). He does not, however, draw any link between appearances of "delicatesse" in the postbellum world and the most pressing contemporary political questions. Accordingly, the poem's vehement warnings come across as somewhat quixotic: the poet is fighting old battles against "slavery" and European decadence that are no longer relevant or whose terms have shifted substantially.

The parenthetical interpolations on Democracy also evince a new poetic self-consciousness and anxiety. Most of the interpolations take the form of apostrophes to Democracy, who is figured alternatively as mother and warrior in various imagined contexts. Even as the poet asserts his identity with the nation, he is always looking over his shoulder, as it were, toward this feminine figure, who does not consistently provide the reassurance that he seeks. Sometimes he declares that Democracy will triumph over her enemies through the multiplication of her offspring: "(Democracy! while weapons were everywhere aim'd at your breast, / I saw you serenely give birth to children-saw in dreams your dilating form, / Saw you with spreading mantle covering the world)" (208). Other apostrophes, however, register anxiety over the possibility that Democracy may not reproduce herself: ("-Ah, mother! prolific and full in all besides, yet how long barren, barren?)" (198). Still others imploringly ask for Democracy's assurance that he has been a dutiful servant: "(Say, O mother! have I not to your thought been faithful? / Have I not, through life, kept that alone before me?)" (205). The vehemence of the parenthetical passages, alternating between cries of triumph and fears of defeat, threatens to undermine the poem's entire project. Democracy may survive or die ignominiously, yet it is not altogether clear how the poet can help her. Indeed, one effect of these parenthetical sections is to delay the beginning of the "song" of Democracy that the Phantom had demanded. If much of the poem functions as an 
attempt to access the inspiration that this song will require, then the parenthetical sections function as so many interruptions, so many chances for the poet to second-guess himself.

In section 9, the poet explains the purpose behind the Phantom's injunction to him: "I heard the voice arising, demanding bards; / By them, all native and grand - by them only can The States be fused into the compact organism of a nation" (198). The second of these two lines had been present in the 1856 poem, but the first line, with its allusion to the Phantom, changes the meaning of the second line in the 1867 text. At this point, the vague and improbable "dangers" to Democracy that the poem had invoked before are replaced by a more comprehensible fear that the States might not be "fused" back together, that even political reunification will not be enough to heal the divisions and resentments caused by the war. Interestingly enough, however, when he finally begins his chant in section 19, filled "with the power's pulsations," he conjures up the past rather than the future: "The loftiest bards of past ages strode before me, / Strange, large men, long unwaked, undisclosed, were disclosed to me" (210). His inspiration, it seems, has betrayed him, and he has to chide his own poetry for not delivering the appropriate vision: "O my rapt song, my charm-mock me not! / Not for the bards of the past . . . / Bards for my own land, ere I go, I invoke" (210). The poem ends, then, in a failure that seems both regrettable and strangely moving. If there are no visions of American unity to be found in the great works of the past, these works at least reflect a time when the power of poets was less in doubt and their ability to embody a collective consciousness less impaired. The war has removed the possibility that Whitman, the nation, and the American people can be so easily equated. Although Whitman admits that if he is to maintain this identification, he must also admit that the war, logically speaking, "was you and me," he determines, in section 17, that now "[he] will henceforth forget" (207). To forget the war and its legacy, to recapture the innocent sense of identification between poet, nation, and people that the war had disrupted - these aims, oriented toward the past rather than the future, seem oddly compatible with Whitman's unwitting invocation of "the loftiest bards of past ages" and suggest that in the Reconstruction era, the poet can no longer conflate himself with the United States without producing unintended ironies.

The move to impeach Andrew Johnson in 1868 would illustrate how divided the nation was between those who wished to readmit the South swiftly and leave the implementation of African-American suffrage to the states, and those who looked to a more centralized federal government to guarantee African-American rights and punish the South for its crimes. ${ }^{16}$ Whitman, who in 1867 favored a gradualist approach to the enfranchisement of the newly freed slaves but feared the specter of 
black political power, regarded the black-dominated Reconstruction governments of South Carolina, Mississippi, and Louisiana as "a temporary, deserv'd punishment for [those states'] Slavery and Secession sins" and insisted that "as a permanency of course [it] is not to be consider'd for a moment." 17 As late as 1872 , in fact, Whitman would oppose the Fifteenth Amendment on the grounds that it was premature, and that the need for a firm Union superseded the need to guarantee African-American rights. ${ }^{18}$ These political views are perfectly in keeping with the pro-Union sentiment expressed in "As I sat Alone by Blue Ontario's Shore"; after all, the task to fuse the nation back together would certainly prove more complicated as long as the debates surrounding voting rights and political representation continued to provoke antagonism between North and South. By channeling his pro-Union opinions into the poem's poetic aspirations, Whitman reduces his politics to ineffectual nostalgia for a lost, state-centered Union instead of engaging with the issues of the present. As a result, his claims of identification with America as it actually exists during the Reconstruction years ring increasingly hollow.

Democratic Vistas, a more overtly political text than "As I sat Alone by Blue Ontario's Shore," was originally conceived as a rejoinder to Thomas Carlyle's essay "Shooting Niagara: And After?," which had appeared in the August 1867 issue of Horace Greeley's Tribune and had aroused Whitman's ire. Although specifically a response to Disraeli's Reform Bill, which was about to enfranchise much of the working class in Britain, "Shooting Niagara" is more generally a condemnation of democratic government as such. According to Carlyle, the height of democratic Schwärmerei had just been demonstrated by the recent American Civil War, in which

[a] continent of the earth has been submerged, for certain years, by deluges as from the Pit of Hell; half a million ... of excellent White Men, full of gifts and faculty, have torn and slashed one another into horrid death, in a temporary humour, which will leave centuries of remembrance fierce enough: and three million absurd Blacks, men and brothers (of a sort), are completely "emancipated"; launched into the career of improvement-likely to be "improved off the face of the earth" in a generation or two! 19

Whitman first responded to Carlyle's argument with an essay, entitled "Democracy," which appeared in the December 1867 issue of Galaxy. He then published a companion essay, "Personalism," in the May 1868 issue. These two texts, cobbled together and prefaced with passages from a third, unpublished essay, became the basis for Democratic Vistas, which appeared in 1871 . 
Despite Whitman's hostility to Carlyle, his response does not take the form of polemical refutation and even acknowledges the justice of many of Carlyle's criticisms. Indeed, so scathing is Whitman's description of the American scene that Democratic Vistas has been viewed by some as a companion to Mark Twain and Charles Dudley Warner's The Gilded Age, a searing denunciation of the greed, hypocrisy, and lack of idealism that many saw as endemic to postbellum American life. Even Whitman's diction resembles Carlyle's in its lofty condemnation:

Never was there, perhaps, more hollowness at heart than at present, and here in the United States. Genuine belief seems to have left us. The underlying principles of the States are not honestly believ'd in, (for all this hectic glow, and these melodramatic screamings,) nor is humanity itself believ'd in. What penetrating eye does not everywhere see through the mask? The spectacle is appalling. We live in an atmosphere of hypocrisy throughout. . . . The depravity of our business classes of our country is not less than has been supposed, but infinitely greater. The official services of America, national, state, and municipal, in all their branches and departments, except the judiciary, are saturated in corruption, bribery, falsehood, mal-administration; and the judiciary is tainted. The great cities reek with respectable as much as non-respectable robbery and scoundrelism. In fashionable life, flippancy, tepid amours, weak infidelism, small aims, or no aims at all, only to kill time. In business, (this all-devouring modern word, business, ) the one sole object is, by any means, pecuniary gain. The magician's serpent in the fable ate up all the other serpents; and money-making is our magician's serpent, remaining today sole master of the field. (PW 369-370)

And yet, even in such squalid conditions, the American people simply need to rediscover their essential greatness, through the help of what Whitman calls "the divine literatus"(365), and this recognition will prove their salvation. Formally, Whitman's argument belongs, as Sacvan Bercovitch has noted, to the tradition of the jeremiad that extends in the United States back to the Puritans of Massachusetts Bay: it invokes the wretchedness of the present moment and intimates the possibility of collapse only to effect, when all seems lost, "a total reversal of perspective" that reveals a glorious future. ${ }^{20}$ The use of the jeremiad allows Whitman to grant that Carlyle's indictment of democracy has its merits, but it also suggests that Carlyle, for all his visionary quality, lacks the world-historical perspective that would enable him to see the millennial democratic future already inscribed in the present.

Carlyle, of course, is not the only one who has this particular difficulty: if the glories of democracy are not just latent but already evident in the people, then why does such a gap between the present and the future exist at all? The Puritans could interpret their tribulations as God's loving chastisement and see in them evidence of his continued favor, but how does a prophet who lacks a Christian framework account for the sordid national scene? Whitman attempts to forestall this objection in the opening pages of Democratic Vistas by admitting that his text "may be open to the charge of one part contradicting another-for there are 
opposite sides to the great question of democracy, as to every great question" (362-363). Certainly the fact that Democratic Vistas grew out of two essays on different topics contributes to this sense of contradiction. "Democracy" had attempted to answer Carlyle's accusation of "Swarmery" by affirming a fundamental faith in the common people, while "Personalism" had celebrated "the pride and centripetal isolation of a human being in himself" (391). In his attempt to reconcile them, Whitman revisits the conception of the poet and the nation that he had elaborated in "Ontario's Shore," but now adds a new and significant element to this conception by drawing on the work of Hegel, whom he had first begun to acknowledge as a kindred spirit in the $1860 \mathrm{~s}^{21}$

Commentators who have recognized Hegel's influence on Democratic Vistas have often connected it to Whitman's use of a dialectical method that both negates and incorporates what it opposes. Immediately after stating that "our task" is to reconcile the contradiction between "democracy" and "personalism," Whitman encourages his readers to view it as apparent instead of real: "I feel the parts harmoniously blended in my own realization and convictions, and present them to be read only in such oneness. . . ." (363, my emphasis). Moreover, he states that the conclusions he has reached are not "the result of studying up in political economy, but of the ordinary sense, observing, wandering among men, these States, these stirring years of war and peace" (363). His experience, it would seem, is enough to resolve the contradiction, so we need not grapple with it at all: we only have to listen and take his message to heart.

Such an appeal to experience as the key that will resolve contradictions is, to say the least, dubious. Yet this appeal is entirely consistent not just with the assertions of One Identity that Whitman continually voices in his poetry, but also with Hegel's definition of the dialectic. In the introduction to the Phenomenology of Spirit, Hegel writes:

Inasmuch as the new true object issues from it, this dialectical movement which consciousness exercises on itself and which affects both its knowledge and its object, is precisely what is called experience [Erfahrung]. ${ }^{22}$

If we are to accept this definition, then dialectic is not a method to be employed, a tool that allows thinkers to work through the contradictions of history, projecting its likely future. Instead, dialectic simply means consciousness coming to full awareness of itself and its object-an awareness that must ultimately abolish any distinction between that consciousness and its object. Whitman's repeated assertions of One Identity that encompasses poet, nation, and people are thus easily comprehensible as a variation on Hegel's monism, one that differs only in that the poetor, to use the term from Democratic Vistas, the "divine literatus"-substitutes for Hegel's philosopher as the one who has achieved this full 
realization. Dialectic may have a temporal dimension-Consciousness, after all, does not achieve its full awareness all at once-but in one sense this temporality is misleading, for dialectic is more properly understood as the structure of reality itself, which only the poet (or, for Hegel, the philosopher) can perceive in its totality but in which all participate. If "experience" and the movement of the dialectic are the same, then there can be no question of "using" a dialectical method in the service of a political program, as Marx did. ${ }^{23}$ By the same token, Whitman can offer no political program in Democratic Vistas, merely a profession of faith and a call for others to see. Even his feminism in this text-a focus of recent critical investigation-is not presented as advocacy but as description and prophecy: "The day is coming when the deep questions of women's entrance amid the arenas of practical life . . . may be put to decision, and real experiment" (401). ${ }^{24}$

Perhaps the most striking implication of Whitman's Hegelianism in Democratic Vistas is that it allows him to avoid the problem that had so troubled him in the 1867 version of "Ontario's Shore"- the possibility that the States might not be "fused" into their "organic compact" after the Civil War. After all, from the perspective of the "literatus," even that war did not reflect a genuine division within the American people. In "Origins of Attempted Secession," another essay written during Reconstruction, Whitman makes this claim explicit, casting the war "not as a struggle of two distinct and separate peoples, but a conflict . . . between the passions and paradoxes of one and the same identity" ( $P W$ 426-427). Blame for the war, then, rests with neither North nor South, but with "a resolute and arrogant determination on the part of the extreme slaveholders, the Calhounites, to carry the states' rights portion of the constitutional compact to its farthest verge, and nationalize slavery, or else disrupt the Union, and found a new empire" (431). Whether these "Calhounites" count as Americans at all seems an open question: if they are Americans, they are certainly treasonous, but even at their worst, they can merely provoke the nation's "passions and paradoxes." The Union cannot actually be disrupted, and only someone alien to America could even conceive of such an absurd project.

By limiting the motive of secession to this small, possibly "foreign" element of slaveholders, Whitman absolves the mass of Confederate soldiers and sympathizers from any taint of disloyalty. Accordingly, in Democratic Vistas he claims that even in their armed struggle against the Union, the southern soldiers were actually proving its democratic ideals:

The People, of their own choice, fighting, dying for their own idea, insolently attack'd by the secession-slave-power, and its very existence imperil'd ... We have seen the alacrity with which the American born populace, the peaceablest and most good-na- 
tured race in the world . . . sprang, at the first tap of the drum, to arms . . . for the life, the safety of the flag. . . .

What have we here, if not, towering above all talk and argument, the plentifullysupplied, last-needed proof of democracy, in its personalities? Curiously enough, too, the proof on this point comes, I should say, every bit as much from the south, as from the north. Although I have spoken only of the later, yet I deliberately include all. Grand, common stock! to me the accomplish'd and convincing growth, prophetic of the future; proof undeniable to sharpest sense, of perfect beauty, tenderness, and pluck, that never feudal lord, nor Greek, nor Roman breed, yet rival'd. Let no tongue ever speak in disparagement of the American races, north or south, who has been through the war in the great army hospitals. (PW 377-379)

For Whitman, it does not matter that the southern soldiers, however they may have justified their actions, were certainly not fighting against "the secession-slave-power." Nor does it suffice to praise their heroism on the battlefield or even to suggest similarities between their bravery and that of their northern counterparts: their conduct must be seen as proof of American "personalities," of the inevitable triumph of democracy, and of the indissolubility of the Union.

In addition to offering Whitman a chance to deny the reality of the war, Hegel's philosophy provides a new justification for Whitman's poetic authority. As he had done in "Ontario's Shore," Whitman enacts in Democratic Vistas a model of authority in which he gives his individual self over to an impersonal poetic power but in doing so establishes his cultural centrality all the more firmly. Indeed, given the dire conditions of the present, the "literatus" is more important than ever, for only he can awaken the people to a consciousness of their true merit:

Our fundamental want to-day in the United States, with closest, amplest reference to our present conditions, and to the future, is of a class, and the clear idea of a class, of native authors, literatuses, far different, far higher in grade than any yet known, sacerdotal, modern, fit to cope with our occasions, lands, permeating the whole mass of American mentality, taste, belief, breathing into it a new breath of life, giving it decision, affecting politics far more than the popular superficial suffrage, with results inside and underneath the elections of Presidents or Congresses-radiating, begetting appropriate teachers, schools, manners, and, as its grandest result, accomplishing, (what neither the schools nor the churches and their clergy have hitherto accomplish'd, and without which this nation will no more stand, permanently, soundly, than a house will stand without a substratum, ) a religious and moral character beneath the political and productive and intellectual bases of the States. ( $P W 365)$

Even as he deplores the absence of "literatuses," Whitman's characterization of himself in this role is evident. It is of course possible to read this passage as a program like the one Matthew Arnold proposes in Culture and Anarchy to uplift the brutalized working classes and spiritually impoverished middle classes through the general dissemination of "culture." 25 Yet the literatus's role is not merely cultural; it is religious in the highest degree: "[T]he problem of humanity all over the civilized 
world is social and religious, and is to be finally met and treated by literature. The priest departs, the divine literatus comes" (365). Just as the priest mediates between the people and God, Whitman's literatus provides a link between the people and transcendence, but he does so precisely by awakening the people to the truth of their own transcendence. Here Whitman's argument parallels Hegel's to an uncanny degree: just as Hegel the philosopher stands at the end of history, having seen and understood the culmination of history's grand narrative in the arrival of Napoleon on the world stage, Whitman here proposes the end of history in the rise of the United States. ${ }^{26}$ There is still work to be done, for the end of history means not the end of time but the end of historical teleology, and the realization of this end remains incomplete. In the most important sense, however, victory has already been won: democracy is destined not to conquer just the United States, but the world, and the poets who will go on proclaiming it will not only be "possess'd of the religious fire and abandon of Isaiah, luxuriant in the epic talent of Homer, or for proud characters as in Shakespeare, but [also] consistent with the Hegelian formulas, and consistent with modern science" (421). Whitman is, in short, a true precursor to Francis Fukuyama. ${ }^{27}$ That conservative commentator David Brooks has recently published a defense of Democratic Vistas, in which he holds up Whitman's jeremiad as a riposte to snobbish critics who love to "say something stupid about America," only confirms how easily the text can be made to serve a complacency that refuses to be unduly troubled by even the most blatant departures from a democratic ideal. ${ }^{28}$

What then, does the end of history look like? For all his staunch optimism in Democratic Vistas, Whitman's attempts to move beyond "this present vagueness" and to suggest "the democratic ethnology of the future" (396) culminate in a portrait of a community that would have already seemed nostalgic in the 1860s:

I can conceive a community . . . in which, on a sufficient scale, the perfect personalities, without noise meet; say in some pleasant western settlement or town, where a couple hundred best men and women, of ordinary worldly status, have been by luck drawn together, with nothing extra of genius or wealth, but virtuous, chaste, industrious, cheerful, resolute, friendly and devout. I can conceive such a community organized in running order, powers judiciously delegated - farming, building, trade, courts, mails, schools, elections, all attended to; and then the rest of life, the main thing, freely branching and blossoming in every individual, and bearing golden fruit. . . . Perhaps, unsung, undramatized, unput in essays or biographies - perhaps even some such community already exists, in Ohio, Illinois, Missouri, or somewhere, practically fulfilling itself, and thus outvying, in cheapest vulgar life, all that has been hitherto shown in best ideal pictures. (402)

Conspicuously absent from this portrait are the forces associated with industrial capitalism that were already transforming American society: mechanization, urbanization, and bureaucratization. This omission is 
striking, since for all Whitman's revulsion at the spectacle of greed and exploitation in America, he had nevertheless acknowledged earlier in Democratic Vistas that capitalism is a double-edged sword, expanding the basis of material life and making possible the preconditions for freedom: "I perceive clearly that the extreme business energy, and this almost maniacal appetite for wealth prevalent in the United States, are parts of amelioration and progress. . . . My theory includes riches, and the getting of riches, and the amplest products, power, activity, inventions, movements, \&c" (384-385). Whitman's ideal community, however, harkens back to the idealized Jeffersonian republic rather than to the industrial capitalist present and future - and in doing so, becomes little more than an exercise in nostalgia. Like such twentieth-century novels as Cather's A Lost Lady and Fitzgerald's The Great Gatsby, Democratic Vistas takes refuge from the distortions of the present in a mythic past, differing from them only in its assertion that this "past" is also the present, awaiting only Americans' consciousness of their merit to revivify its plenitude. Such a refusal to engage with the complexities of the present moment, for a thinker committed to a democratic ideal, can only prove self-defeating.

Democratic Vistas, with its overtly Hegelian structure, offers a more intellectually coherent account of what Whitman's notion of the American poet entails than "Ontario's Shore" had done, and yet it also reveals, more clearly than any of Whitman's previous work, the conservatism into which such a notion of poetic practice too quickly collapses. Critics who have remarked on Whitman's conservative "turn" after the war often locate it in precise shifts from his earlier practice: the move away from identification with African-Americans that had characterized "Song of Myself," coupled with a growing interest in racist theories of evolution; the return to more regular metrical forms and stanzas in Drum-Taps; the increasing emphasis on religion; and even the possibility that the end of the Civil War-and thus the end of effective alternatives to Whitman's mystical Unionism - simply drained his work of creative tension and made him complacent. ${ }^{29} \mathrm{I}$ would maintain, however, that for all the egalitarian sentiment that Whitman maintained throughout his career, both his antebellum and postbellum poetry in fact show a frustration with politics that flows directly from his desire to identify himself with the nation, to unite his poetic will with an American democratic essence. Indeed, the fact that he went on reprinting his most celebrated poems from the 1855 Leaves of Grass even as he contained them within the larger wholes of subsequent editions of that work suggests that he saw no irreconcilable opposition between the professions of radicalism for which he is now celebrated and the religious mysticism that many of his earliest readers discerned. His 1892 "Deathbed" edition of Leaves of Grass thus functions like one of his catalogues, emptying out the radical specificity of many of its individual poems as it strives to- 
ward transcendence. And his final poetic meditation on Hegel, the brief 1881 poem "Roaming in Thought (After reading HEGEL)," provides a fitting summary of his overall aims: "Roaming in thought over the Universe, I saw the little that is Good steadily hastening towards immortality, / And the vast all that is call'd Evil I saw hastening to merge itself and become lost and dead" (685). If we are to associate American democracy with "the little that is Good," then surely its triumph "in thought" involves its ability to absorb without combating the vast "Evil" to which it is ostensibly opposed.

What political value is there to be gained from the particular conflation of poet, self, and nation that we see in Whitman's poetry, a conflation that assumes a Hegelian logic in Democratic Vistas? Perhaps we must locate such value in the utopian glimpse of the collective that Whitman offers in his unswerving identification of poet, nation, and whole. The loss of "boundaries" between selves has implications not just for the proliferation of pleasures and identities that queer theorists have identified in Whitman's work, but in the possibility that we might see, through the light provided by the "divine literatus," a glimpse of what it might be like to live without the injury and burden of individuality. For those who regard progressive politics not just as the possibility for the free development of human capacities but as the transcendence of the individual altogether (Fredric Jameson, for instance, comes to mind), Whitman's use of Hegelian logic can be suggestive ${ }^{30}$ And yet, even this glimpse of the utopian must be viewed against the intractability of history, against the need to work through the contradictions of the present instead of fleeing from them. Without an acknowledgment of the real difficulty of struggle, Whitman's end of history falls immediately into a regression all too characteristic, as Eagleton has suggested, of bourgeois aesthetics and ideology - a "wan hope, in an increasingly rationalized, secularized, demythologized environment, that ultimate purpose and meaning may not be entirely lost" (88). It is perhaps a tragic irony that Whitman's passionate belief in democracy collapses into nostalgia, yearning for "ultimate purpose and meaning," and a wishful flight from history in the ruthlessly "demythologized environment" of the United States during Reconstruction.

\section{University of Tennessee, Knoxville}

\section{NOTES}

I am grateful to Joseph Black, Hester Blum, Jonathan Eburne, Amy Elias, Teresa Goddu, Bob Leggett, Urmila Seshagiri, Honor McKitrick Wallace, and John Zomchick, whose careful reading of this essay and suggestions for revision have improved it considerably. 
1 Betsy Erkkila, Whitman the Political Poet (New York and Oxford: Oxford University Press, 1989), 7. Richard Maurice Bucke's influential reading of Whitman in Walt Whitman (Philadelphia: David McKay, 1883) explicitly defines Leaves of Grass as the sacred scripture of "a religious era not yet reached" in American civilization (183). Though many of his successors have made much more modest claims for Leaves of Grass, Bucke's categorization of the text has, according to Erkkila, cast a long shadow.

2 See, for instance, Michael Moon, Disseminating Whitman: Revision and Corporeality in Leaves of Grass (Cambridge: Harvard University Press, 1991). For Moon, Whitman's great achievement is that "relations among (male) persons/bodies [are] rendered totally fluid, all barriers to their merging 'washed away"' (14). Such an achievement entails not just the liberation of desires, but a critique of the sovereign individual and the liberal political order of the United States. Yet if this is an accurate reading of Whitman's central project, we must keep in mind how inconsistently the poetry achieves it. As Vivian R. Pollak argues in The Erotic Whitman (Berkeley: University of California Press, 2000), the poetry, for all its equalization of desires, "liberates some forbidden voices and silences others. Some emancipations demonstrably matter more to Whitman, as do some persons" (xvii).

3 In "Whitman and Race: 'He's Queer, He's Unclear, Get Used to It" (Fournal of American Studies 36 [August 2002], 293-318), Paul H. Outka summarizes the three most common positions of those who have confronted the contradiction between Whitman's racial views in his poetry and his journalism: "1) The New Critical view that Whitman's poetry is all that really matters, and his unenlightened political views are so much dross on his genius; 2) the notion that the journalism in fact represents the 'real' Whitman, or at least has similar authority to the poetry . . . and 3) the idea that the division represents contradictions in both America and Whitman's own psyche, contradictions that Whitman tried, somewhat desperately, to repress, cover up, or ameliorate by writing great poetry" (300). Outka then proposes an account of Whitman's work that stresses its opportunities for erotic transgression instead: "The racist journalist and the progressive poet form not a contradiction or continuum, but a circuit, the binding and release of eroticized political energies" (302). Outka's valorization of erotic transgression here owes much to recent queer theory and, like much of it, risks substituting mere transgression for political transformation.

4 In "'Hinting' and 'Reminding': The Rhetoric of Performative Embodiment in Leaves of Grass" (ELH 69 [Winter 2002], 1047-1082), Vincent J. Bertolini has recently warned that although "the author of Leaves of Grass, who has his speaker name himself 'Walt Whitman,' continually tempts the reader to identify the speaking 'I' of his lyric with him, he also repeatedly deflects those identifications, inviting the reader instead to see the self gaining expression in the poetry as 'being realized'-being instantiated, rendered real, brought into being - through the reader's participatory agency" (1048). Yet Bertolini's argument is not entirely consistent: he remains interested in the intentions and political effects of Whitman the author, which can be discerned through the poetry even if we do not identify the lyric speaker of the poems with the poet. Even if the author intends for us to "realize" our own individual versions of the self in the poem, we are meant to grasp this as Whitman's goal.

5 Walt Whitman, "So Long!," in Leaves of Grass: A Textual Variorum of the Printed Poems, ed. Sculley Bradley, Harold W. Blodgett, Arthur Golden, and William White (New York: New York University Press, 1980), 452. All further citations from Whitman's poetry will be from this edition.

6 Terry Eagleton, The Ideology of the Aesthetic (Oxford: Blackwell, 1990), 70.

7 D. H. Lawrence, Studies in Classic American Literature (1923; rpt. New York: Viking, 1961), 169. 
8 See Kerry A. Larson, Whitman's Drama of Consensus (Chicago: University of Chicago Press, 1988). Larson's reading of the rhetorical questions in "Crossing Brooklyn Ferry" is instructive: "Questions like these do not expect answers, only assent; to respond otherwise would not only be a confession of misplaced emphasis but, one supposes, an act of disqualification. Either we understand or we do not" (12). Given such an admission that Whitman frequently makes debate impossible, it is surprising that Larson continues to recuperate a possibility for progressive politics in Whitman under the rubric "conservative radicalism" ( $\mathrm{xx}$ ).

9 Indeed, the unpublished 1856 political tract "The Eighteenth Presidency!" (in Walt Whitman, Poetry and Prose [New York: Library of America, 1982], 1307-1325) poses the contradiction between Whitman's oppositional stance and his desire for unity most starkly. After denouncing the current President, Franklin Pierce, as a man who "eats dirt and excrement for his daily meals, likes it, and tries to force it on The States" (1310), Whitman rejects the notion that meaningful opposition can exist within the American system. Party platforms, for instance, are mere "impudence" (1317) because they falsely suggest irreconcilable visions of the common good. Instead of parties, Whitman lauds "THE UNCHANGEABLE AMERICAN PLATFORMS," which "are simply the organic compacts of The States, the Declaration of Independence, the Federal Constitution, the actions of the earlier Congresses, the spirit of the fathers and warriors, the official lives of Washington, Jefferson, Madison, and the now well-understood and morally established rights of man, wherever the sun shines, the rain falls, and the grass grows" (1318). The belief that one could interpret these documents and this history in divergent ways thus becomes the essential act of betrayal.

10 As my invocation of an "imagined community" suggests, I am largely in agreement with Benedict Anderson's claim in Imagined Communities: Reflections on the Origin and Spread of Nationalism (revised edition, London: Verso, 1991) that communities "are to be distinguished, not by their falsity/genuineness, but by the style in which they are imagined" (6). I would add, however, that Anderson has not considered the problem posed by the Civil War, which Whitman is forced to confront: how does an imagined community account for ruptures in its story of itself, or imagine a history in which these ruptures become meaningful without destroying the community's sense of continuity?

11 The poem would undergo further revision in later editions of Leaves of Grass, but these changes would be minor compared to the drastic overhaul of 1867 . In 1871, the poem would introduce the "Marches Now the War is Over" section. Finally, in the 1881 edition it would assume its present form and title- "By Blue Ontario's Shore"and would stand alone following the "Memories of President Lincoln" cluster. For a detailed account of these revisions, see Gary A. Culbert, "Whitman's Revisions of 'By Blue Ontario's Shore," in Walt Whitman Review 23 (1977), 35-45.

12 See Mark Maslan, Whitman Possessed: Poetry, Sexuality, and Popular Authority (Baltimore: Johns Hopkins University Press, 2001), 1-4, 93-141.

13 This obvious borrowing from the Preface has been one reason for the relatively unfavorable critical response to the poem; Culbert, for instance, opines, "One is perhaps justified in scoffing at such a method of making poetry" (36). That Whitman can pass so easily from prose to poetry, however, suggests that the generic distinctions between them may be less important in his œuvre than some critics' efforts to oppose the two (the contrast between racist journalist and great poet, for instance) would suggest. 
14 See Harold Bloom, The Anxiety of Influence: $A$ Theory of Poetry (New York: Oxford University Press, 1973). Within the terms of Bloom's theory, Whitman not only establishes his "strength" against his predecessors but forestalls challenges from those who follow him.

15 In the 1856 "Poem of Many In One," these lines had read: "Slavery, the tremulous spreading of hands to shelter it - the stern opposition to it, which ceases only when it ceases" (196). This line, which was retained in the 1860 edition but deleted in all subsequent versions, makes more sense as the closing of Whitman's catalogue, since the "stern opposition" becomes the proof of the people's virtue. It may be that in the 1867 version, Whitman means to imply that the legacy of slavery persists and that the struggle cannot end until all its pernicious effects have been expunged. Yet given Whitman's belief that the reintegration of the Union should take precedence over any attempt to secure African-American rights-which I shall discuss below-such a reading seems unlikely.

16 For a general discussion of the conflict surrounding the attempt to impeach Johnson, see Eric Foner, A Short History of Reconstruction, 1863-1877 (New York: Harper and Row, 1990), 142-144; on Whitman's own support for and involvement in the Johnson administration, see David W. Blight, Race and Reunion: The Civil War in American Memory (Cambridge: Belknap Press of Harvard University Press, 2001), 2122; and David S. Reynolds, Walt Whitman's America: A Cultural Biography (New York: Knopf, 1995), 463-469.

17 Walt Whitman, Memoranda During the War, in Prose Works 1892, ed. Floyd Stovall (New York: New York University Press, 1964), 326. Subsequent quotations from Whitman's prose will be cited parenthetically from this edition.

18 According to Horace Traubel, Whitman "took the ground that the Negro franchise would never be truly granted till the Negro vote was a divided, not a class one"that is, until it became certain that African-Americans would not vote merely as a bloc (quoted in Martin Klammer, Whitman, Slavery, and the Emergence of Leaves of Grass [University Park, PA: Pennsylvania State University Press, 1995], 162).

19 Thomas Carlyle, "Shooting Niagara: And After?" (1867; rpt. in Collected Works [London: Chapman and Hall, 1870-1887] 30:7.

20 Sacvan Bercovitch, The American feremiad (Madison: University of Wisconsin Press, 1978), 198. Whitman replaces the Calvinist Christianity of the Puritans with his own quasi-religious nationalism, but the structure of his argument in Democratic Vistas retains the same form of the Puritan jeremiads that Bercovitch identifies.

21 On Whitman's turn toward Hegel in the 1860s, see Reynolds, 253-255, 449-450, 480-483. For a more detailed account of Whitman's use of Hegel, see especially Kathryne V. Lindberg, "Whitman's 'Convertible Terms': America, Self, Ideology," in Theorizing American Literature: Hegel, the Sign, and History, ed. Bainard Cowan and Joseph G. Kronick (Baton Rouge and London: Louisiana State University Press, 1991), 233-268. I am largely in agreement with Lindberg's analysis, particularly her shrewd account of how Whitman reverses Hegel's claims for philosophy: "Whereas most Hegelians are somewhat uncertain about literature's position as that which philosophy must eventually overcome, Whitman clearly asserts the historical priority and the privilege literature enjoys over philosophy and other discourses" (261).

22 G. W. F. Hegel, Phenomenology of Spirit, trans. A.V. Miller (Oxford: Oxford University Press, 1977), 60. 
23 My reading of Hegel owes much to Alexandre Kojève's Introduction to the Reading of Hegel: Lectures on the Phenomenology of Spirit, ed. Allan Bloom, trans. James H. Nichols, Jr. (Ithaca: Cornell University Press, 1980). Kojève insists-I believe correctly - that "[ $\mathrm{t}$ ] he Hegelian method, therefore, is not at all 'dialectical'; it is purely contemplative and descriptive, or better, phenomenological in Husserl's sense of the term" (171). Such a definition of the dialectic, however, does not allow for the kind of productive, critical use of dialectical thinking that Marx called for in his radical revisioning of Hegel. I maintain that Whitman's own dialectical forays in Democratic Vistas are strictly Hegelian instead of Marxist, and thus are easily co-opted by a conservative politics. For a useful discussion of the differences between the Hegelian and the Marxist versions of the dialectic - and of their political implications - see Louis Althusser, "Contradiction and Overdetermination," in For Marx, trans. Ben Brewster (New York: Pantheon Books, 1969).

24 For a discussion of Whitman's feminism in Democratic Vistas, see Pollak (172193).

25 See, for instance, Erkkila's comparison of Democratic Vistas and Culture and Anarchy in Whitman: The Political Poet, which acknowledges the similarities between the two texts but sees in Whitman's vision of culture a rejection of "the hegemonic dominance of an elite class" that Arnold celebrated and a valorization of "the common life of the masses" (252).

26 On the significance of Napoleon within Hegel's philosophical project as harbinger of the end of history, see Kojève (32-35). Interestingly enough, Hegel, like Whitman, identified the Western Hemisphere as the next arena in which the end of history will be realized. See his Lectures on the Philosophy of World History: Introduction: Reason in History, trans. H.B. Nisbet (1837; rpt. Cambridge: Cambridge University Press, 1975), 170.

27 See Francis Fukuyama, The End of History and the Last Man (New York: Free Press, 1992), which locates a Hegelian "end of history" in the entirely foreseeable triumph of liberal democracy around the world.

28 David Brooks, "What Whitman Knew," in Atlantic Monthly 291 (May 2003), 32.

29 On Whitman's shifting views on African-Americans, see Klammer (160) and Reynolds (468-474); on the reversion to traditional poetic forms in Drum-Taps, see Erkkila (210-212); on the possibility of loss of creative tension after the Civil War, see George B. Hutchinson, The Ecstatic Whitman: Literary Shamanism and the Crisis of the Union (Columbus: Ohio State University Press, 1986), 170-186.

30 See, for instance, Fredric Jameson, The Political Unconscious: Narrative as a Socially Symbolic Act (Ithaca: Cornell University Press, 1981): "The achieved collectivity or organic group of whatever kind-oppressors fully as much as oppressed-is Utopian not in itself, but only insofar as all such collectivities are themselves figures for the ultimate concrete collective life of an achieved Utopian or classless society" (291). If Whitman's Hegelianism allows us to conceive of individuality not as a "choice" but as a fate that we are condemned to inhabit, then even the conservative collectivity of "America" that he portrays in Democratic Vistas can serve the utopian function Jameson describes here-that is, it can intimate "an ultimate concrete collective life." 